\title{
Changing the Rules: State Mortgage Foreclosure Moratoria During the Great Depression
}

\author{
David C. Wheelock
}

\begin{abstract}
Many U.S. states imposed temporary moratoria on farm and nonfarm residential mortgage foreclosures during the Great Depression. This article describes the conditions that led some states to impose these moratoria and other mortgage relief during the Depression and discusses the economic effects. Moratoria were more common in states with large farm populations (as a percentage of total state population) and high farm mortgage foreclosure rates, although nonfarm mortgage distress appears to help explain why a few states with relatively low farm foreclosure rates also imposed moratoria. The moratoria reduced farm foreclosure rates in the short run, but they also appear to have reduced the supply of loans and made credit more expensive for subsequent borrowers. The evidence from the Great Depression demonstrates how government actions to reduce foreclosures can impose costs that should be weighed against potential benefits. (JEL E44, G21, G28, N12, N22)
\end{abstract}

Federal Reserve Bank of St. Louis Review, November/December 2008, 90(6), pp. 569-583.

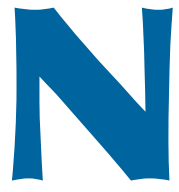

early 1 percent of U.S. home mortgages entered foreclosure during the first quarter of 2008, and almost 2.5 percent of all home mortgages were in foreclosure at the end of the quarter. ${ }^{1}$ The high number of home mortgages in foreclosure or at risk of foreclosure has prompted calls for government action. On July 30, 2008, President Bush signed the Housing and Economic Recovery Act of 2008 (H.R. 3221), which, among other provisions, included a $\$ 300$ billion increase in Federal Housing Administration (FHA) loan guarantees to encourage lenders to refinance delinquent home mortgages. Congress also has considered, among other proposals, directing the Federal National Mortgage Association (Fannie Mae) and

1 The stock of mortgages in foreclosure during a given quarter includes mortgages that entered foreclosure during that quarter and foreclosures that began in previous quarters that have not yet been completed. These data are from the Mortgage Bankers Association (Haver Analytics). the Federal Home Loan Mortgage Association (Freddie Mac) to refinance subprime mortgages, and creating a new federal agency to acquire and refinance delinquent mortgages. ${ }^{2}$

The creation of a new federal agency to purchase delinquent mortgages would mimic a similar agency, the Home Owners' Loan Corporation, which was established to refinance delinquent mortgages during the Great Depression. Mortgage delinquency rates rose sharply during the Depression. By one estimate, approximately half of all U.S. urban home mortgages were delinquent as of January 1, 1934 (Bridewell, 1938, p. 172). The Home Owners' Loan Corporation was established in 1933 and over the subsequent three years purchased and refinanced more than 1 million delinquent home loans. Additional steps by the

2 Fannie Mae and Freddie Mac are the two main governmentsponsored enterprises that purchase and securitize home mortgages.

David C. Wheelock is an assistant vice president and economist at the Federal Reserve Bank of St. Louis. The author thanks Lee Alston, Carlos Garriga, and Rajdeep Sengupta for comments on an earlier version of this article. Craig P. Aubuchon provided research assistance.

(C) 2008, The Federal Reserve Bank of St. Louis. The views expressed in this article are those of the author(s) and do not necessarily reflect the views of the Federal Reserve System, the Board of Governors, or the regional Federal Reserve Banks. Articles may be reprinted, reproduced, published, distributed, displayed, and transmitted in their entirety if copyright notice, author name(s), and full citation are included. Abstracts, synopses, and other derivative works may be made only with prior written permission of the Federal Reserve Bank of St. Louis. 
federal government to ease mortgage market pressures during the 1930s included the creation of the Federal Home Loan Bank System to mobilize funds for home lending, the introduction of FHA mortgage insurance, and the creation of Fannie Mae to purchase FHA-insured loans. ${ }^{3}$

State and local governments also responded to the rise in mortgage foreclosures during the Depression, mainly by changing state laws governing foreclosure. Several states enacted temporary foreclosure moratoria. Others made permanent changes that limited the rights or incentives of lenders to foreclose on mortgaged property. Recently a number of U.S. states have considered similar steps to reduce mortgage foreclosures. During the first six months of 2008, the state legislatures of Massachusetts, Minnesota, and New York considered legislation to impose moratoria on foreclosures, and legislation for a national moratorium was introduced in the U.S. Congress.

Foreclosure moratoria are controversial. Although moratoria can benefit some borrowers and temporarily reduce foreclosures, critics argue that moratoria reduce the supply of loans and increase costs for future borrowers. ${ }^{4}$ Despite similar arguments made during the Great Depression, 27 states imposed moratoria at the time to reduce the number of mortgage foreclosures. ${ }^{5}$ Today, the growing sentiment for using moratoria to reduce the current number of foreclosures prompts a retrospective look at other episodes, such as the Great Depression, when moratoria were used to limit mortgage foreclosures. This article summarizes the main types of mortgage foreclosure laws enacted by U.S. states during the 1930s. Further, it examines why some states elected to impose foreclosure moratoria but others did not. Finally,

\footnotetext{
3 These and other federal government responses to mortgage distress during the Great Depression are described in Wheelock (2008).

4 For example, see Sloan (2008).

5 The federal government also enacted a moratorium on farm mortgage foreclosures during the Great Depression. The Frazier-Lemke Farm Bankruptcy Act of 1934 authorized federal courts to grant a five-year moratorium on foreclosure and to scale down a farmer's debt to the current value of his property. The act was declared unconstitutional by the Supreme Court in 1935. Subsequently, Congress enacted the Frazier-Lemke Farm Mortgage Moratorium Act of 1935, which modified and limited the terms of the moratorium. The constitutionality of the latter act was upheld by the Supreme Court in 1937.
}

it summarizes empirical evidence on the costs of foreclosure moratoria borne by borrowers.

\section{MORTGAGE DISTRESS DURING THE GREAT DEPRESSION}

The Great Depression was a cataclysmic event. Between 1929 and 1933, U.S. personal income declined 44 percent, real output fell by 30 percent, and the unemployment rate climbed to 25 percent of the labor force. U.S. real estate markets were already showing signs of distress before the Great Depression began. The number of nonfarm residential real estate foreclosures doubled between 1926 and 1929. With the onset of the Depression, the number of foreclosures rose still higher, from 134,900 in 1929 to 252,400 in $1933 .{ }^{6}$ The foreclosure rate, shown in Figure 1, increased from 3.6 per 1,000 home mortgages in 1926, the first year data are available, to a high of 13.3 per 1,000 mortgages in 1933. In that year, on average 1,000 home mortgages were foreclosed every day (Federal Home Loan Bank Board, 1937, p. 4). Many more homes were at risk of foreclosure-as many as half of urban home mortgages were delinquent on January 1, 1934 (Bridewell, 1938, p. 172).

The Great Depression also sharply increased farm mortgage foreclosures, which were unusually high throughout the 1920s and 1930s; an average of more than 100,000 farm mortgages entered foreclosure each year from 1926 to 1940. Figure 2 shows that the farm foreclosure rate was especially high from 1932 through 1934, peaking at nearly 39 foreclosures per 1,000 farms in $1933 .^{7}$

The sharp increase in mortgage distress during the Great Depression was the result of precipitous declines in income and real estate values following a period of rapid growth in mortgage debt outstanding. ${ }^{8}$ A rising level of debt does

\footnotetext{
6 Historical Statistics of the United States, Earliest Times to the Present: Millennial Edition (2006), series Dc1255.

7 Alston (1983, Table 1) reports average annual foreclosure rates of 3.2 per 1,000 farms for 1913-20, 10.7 for 1921-25, 19.8 for 1926-40, 3.2 for 1941-50, 1.7 for 1951-60, 1.3 for 1961-70, and 1.3 for 1971-80.

8 See Alston (1983) and Wheelock (2008) for discussion on the growth of farm and nonfarm mortgage debt, respectively, during the 1910s and 1920s.
} 
Figure 1

Nonfarm Real Estate Mortgage Foreclosure Rate, 1926-1941

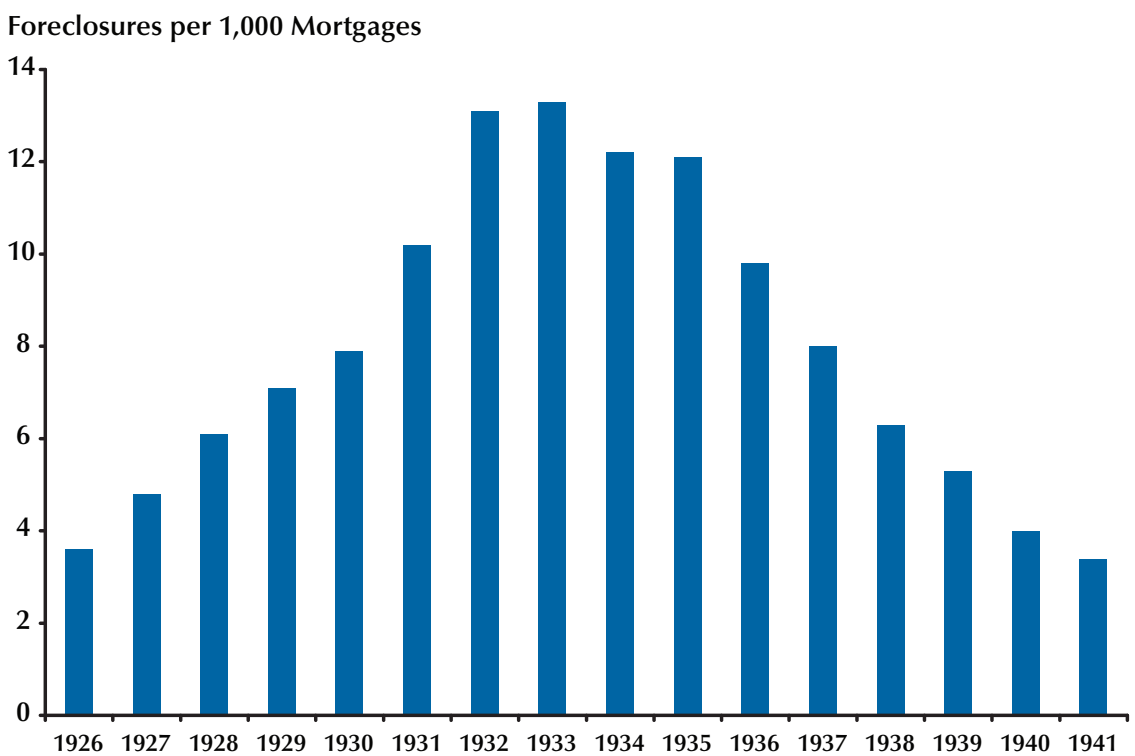

Figure 2

U.S. Farm Foreclosure Rate, 1926-1941

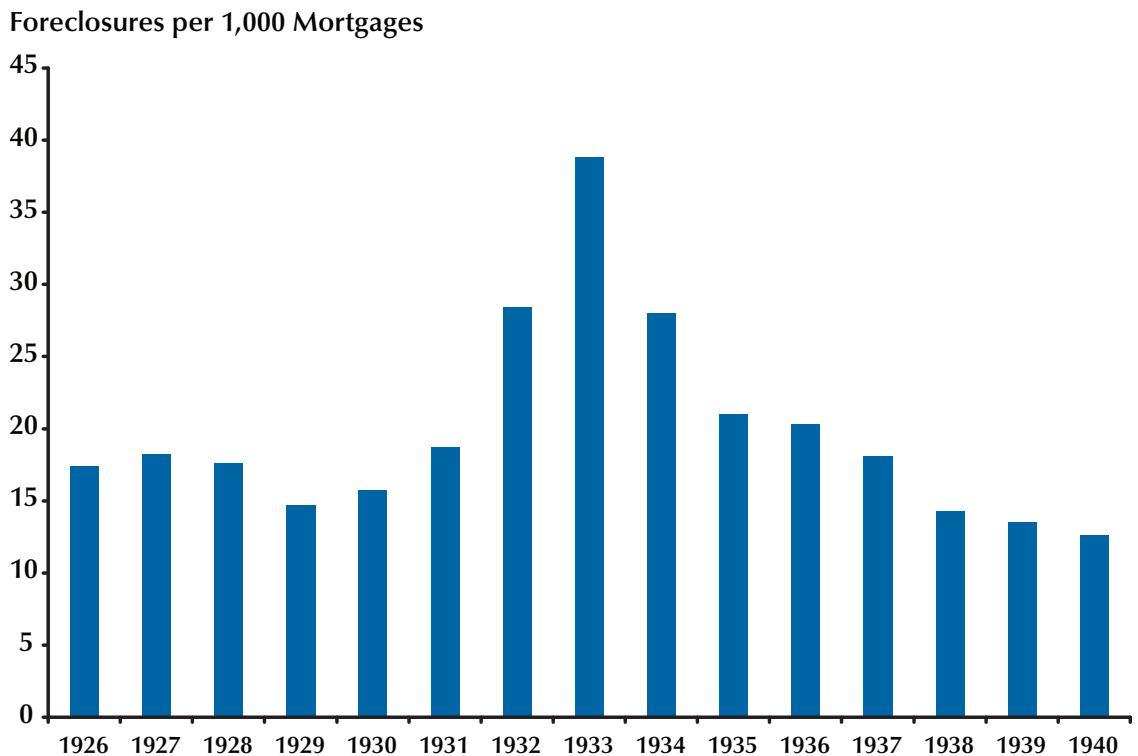


Figure 3

\section{Nonfarm Residential Mortgage Debt as a Percentage of Nonfarm Residential Wealth}

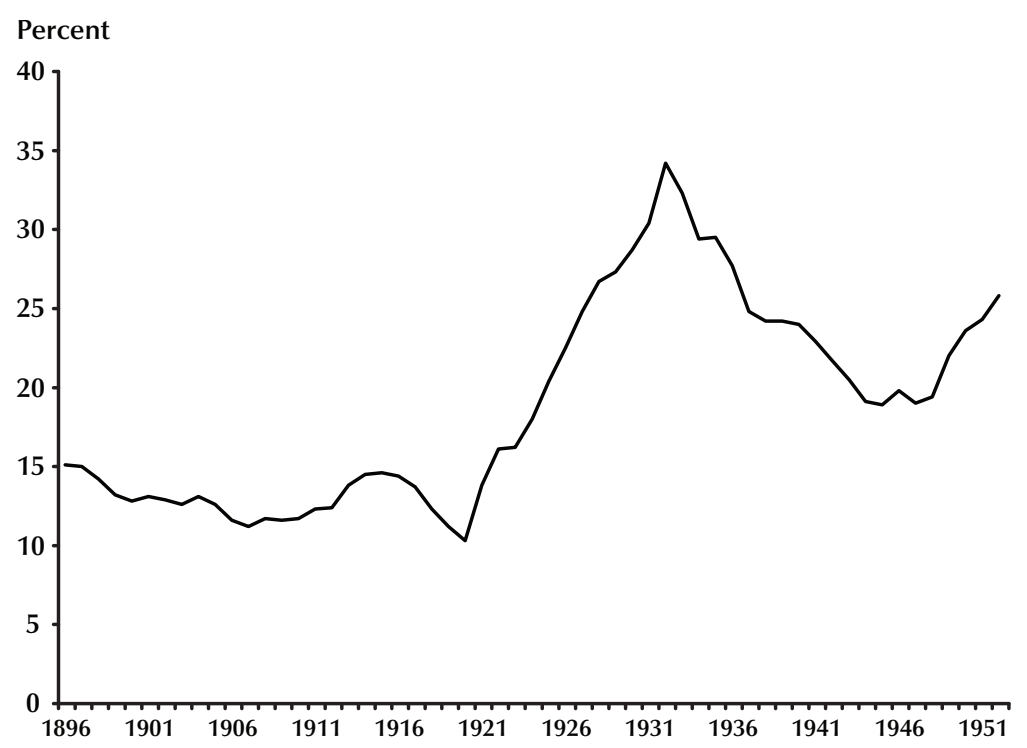

SOURCE: Grebler, Blank, Winnick (1956, table L-6).

not necessarily pose a problem for borrowers, provided their incomes and wealth are sufficient to make loan payments. However, between 1929 and 1932, personal disposable income and nonfarm residential wealth fell 41.0 percent and 25.7 percent, respectively, whereas the value of nonfarm residential debt fell a mere 6.8 percent. As shown in Figure 3, nonfarm residential mortgage debt increased sharply relative to nonfarm residential wealth during the 1920s and continued to rise until 1932. Moreover, falling house prices meant that homeowners who were having difficulty making their mortgage payments were increasingly unlikely to sell their homes for more than the outstanding balances on their loans.

Moreover, many home mortgages were shortterm, nonamortizing loans that typically were refinanced on maturity. ${ }^{9}$ Refinancing usually

9 Mortgage lending terms varied considerably across lenders. Savings and loan associations typically made long-term, amortizing mortgage loans. However, banks and life insurance companies often made short-term, nonamortizing (or only partly amortizing) loans. See Morton (1956) for more information about the mortgage market and loan characteristics during the 1920s and 1930s. was easily accomplished during the 1920s, when household incomes and property values were generally rising, but next to impossible during the Depression. Falling incomes made it increasingly difficult for borrowers to make loan payments or to refinance outstanding loans as they came due. The failure of thousands of banks and other lenders made refinancing difficult even for good borrowers; customer relationships were severed and the costs of credit intermediation rose (Bernanke, 1983). The mix of falling household incomes and property values and short-term, nonamortizing loans resulted in soaring mortgage delinquency and foreclosure rates. ${ }^{10}$

Farmers faced similar problems. U.S. farm income fell from $\$ 6.2$ billion in 1929 to $\$ 2.0$ billion in 1932. At the same time, farm mortgage

\footnotetext{
10 As discussed in Wheelock (2008), federal agencies created during the 1930s to rescue and reform the mortgage market encouraged the use of long-term, amortizing mortgage loans-so-called conventional loans. Nonamortizing, unconventional loans have become more common in recent years, however, which some analysts contend has contributed to the increase in mortgage loan delinquencies and foreclosures since 2006.
} 
debt outstanding rose from 40 percent of the value of farm land and buildings in 1930 to 50 percent in $1935 .{ }^{11}$ Hence, sharply falling incomes made it increasingly difficult for farmers to pay the interest and principal on their outstanding debts, but falling property values made it less likely that farmers could sell their properties for more than the outstanding balance on their mortgages. The result was a sharp increase in farm mortgage delinquencies and foreclosures.

\section{FORECLOSURE RELIEF LEGISLATION}

The first attempts to reduce foreclosures during the Great Depression focused on encouraging lenders and borrowers to renegotiate loan terms through mediation boards and other voluntary arrangements. However, the clamor for compulsory foreclosure moratoria grew louder as the Depression worsened and the number of foreclosures rose. On February 8, 1933, Iowa became the first state to enact a moratorium on mortgage foreclosures. Over the subsequent 18 months, a total of 27 states enacted legislation to limit or halt foreclosures (Skilton, 1944, p. 78).

\section{Mortgage Law}

Mortgages and similar loan contracts often are used to finance the purchase of homes, farms, and other real estate. ${ }^{12}$ The mortgage contract specifies the terms under which the borrower is obligated to make regular payments of principal and interest to retire the loan. If at some point the borrower fails to make the contracted payments, the loan agreement and laws of the state in which the property is located determine the actions the lender may take to enforce the loan contract. The mortgaged property serves as the security or col-

\footnotetext{
${ }^{11}$ Historical Statistics of the United States, Earliest Times to the Present: Millennial Edition (2006), series Da1295 (farm income) and series Da579 (debt as a percentage of land and building value).

12 states. Unlike a mortgage, a deed of trust involves an independent trustee who holds a power of sale in the event of default and who conveys the property to the borrower once the deed of trust is paid in full. See McDonald and Thornton (2008) for basic information about the mortgage market and mortgage finance.
}

lateral for the loan, and if the borrower defaults on the mortgage contract, the lender may foreclose on the property against which the loan was made, subject to the state's laws governing foreclosure.

State laws governing the foreclosure process vary. For example, foreclosure may be judicial or nonjudicial. Under judicial foreclosure, the lender sues the delinquent borrower in court for nonperformance. Typically, judicial foreclosure results in the public sale of the mortgaged property under court supervision, with the proceeds used to satisfy the outstanding mortgage balance and any other outstanding liens on the property.

Under nonjudicial foreclosure by "power of sale," the mortgaged property is sold without court supervision in the event of borrower default, again with the sale proceeds used to pay the outstanding balance of the mortgage and any other liens. Some states permit strict foreclosure, which grants the lender unconditional title to the mortgaged property in the event of borrower default.

The laws of some states grant statutory redemption periods during which a borrower (mortgagor) may regain ownership of a property after foreclosure sale by payment of the foreclosure sale price, interest, and taxes. Generally, redemption is permitted from six months to one year after the foreclosure sale. During the Depression, several states modified their laws to extend or enhance the rights of mortgagors to redeem foreclosed property.

Finally, some states allow deficiency judgments in which a mortgage holder is granted a lien against other assets of the borrower when the proceeds from a sale of the mortgaged property do not cover the outstanding mortgage balance. ${ }^{13}$ During the Depression, several states enacted reforms that limited the rights of lenders to seek deficiency judgments against borrowers.

\section{Examples from the Great Depression}

The diversity of foreclosure proceedings across U.S. states during the 1930s was noted in a 1936 federal government study:

\footnotetext{
${ }^{13}$ If the value of a property exceeds the outstanding loan balance, the borrower generally benefits from refinancing the loan or selling the property and paying off the outstanding loan balance rather than losing the property through foreclosure. Hence, the proceeds from most foreclosure sales are less than the outstanding mortgage balance.
} 
A general survey indicates that in twenty-eight states foreclosure is by action in court. Ten states use unregulated power of sale. Five states use regulated power of sale, and the remaining states have various other methods. Thirty-one states provide a redemption period ranging from four months in Oregon to two years in Alabama. Seventeen states have no redemption period, but, of these, eight use foreclosure in court which requires months to complete. (Central Housing Committee, 1936, p. 2)

During the Depression, many states enhanced borrower redemption rights, limited deficiency judgments, or made other changes that favored borrowers, and several states imposed moratoria on foreclosures. The specific details of moratoria legislation varied widely. A few states imposed blanket moratoria that temporarily prohibited most foreclosures of farm and nonfarm home mortgages contracted before a specified date. However, most states limited their moratoria to specific situations. For example, some states granted relief only for borrowers who were current in the payment of interest and taxes but delinquent in the payment of loan principal. For example, a New York statute enacted in 1933 specified that "No action for the foreclosure of a mortgage on real estate solely on account of default in payment of principal...shall be brought before July 1, 1937” (Central Housing Committee, 1936, p. A-18). Foreclosures were permitted, however, against borrowers who had ceased to pay interest and taxes, as well as principal.

Several states directed their state courts to grant moratoria in deserving cases, but little guidance was provided to the courts about how to determine which borrowers deserved relief. For example, in Iowa, the court was authorized to grant a borrower's request for relief from pending foreclosure unless "good cause is shown to the contrary" (Skilton, 1944, p. 82). Similarly, an Arizona statute specified that "In pending or future real estate mortgage foreclosure suits, the court may order a two-year continuance unless good cause to the contrary is shown" (Central Housing Committee, 1936, p. A-3). Not surprisingly, the extent to which courts granted relief to delinquent borrowers varied widely, even within a state. Many courts determined that it was pointless to grant relief to borrowers who had no hope of refinancing their mortgage or making payments or who did not act in good faith toward their lender (Skilton, 1944, pp. 98-106). In addition, courts often required borrowers to pay rent or interest to the lender, as well as taxes, as a condition for halting foreclosure proceedings.

In conjunction with a foreclosure moratorium, several states extended the period during which a mortgagor could redeem his property after foreclosure. Again, however, any extension of the redemption period was often left to the court's discretion. In Kansas, for example, "the period for redemption on real estate may be extended for such additional time as the court shall deem it just and equitable" (Central Housing Committee, 1936, p. A-10). In a few states, the legislation was more specific. For example, North Dakota legislation specified that "The period within which a mortgagor or judgment debtor may redeem from a mortgage foreclosure or execution sale of real estate...is extended for a period of two years" (Central Housing Committee, 1936, p. A-21).

Several states also modified their statutes to limit deficiency judgments. Some states restricted judgments to the difference between the outstanding loan balance and a "fair" or "reasonable" value of the mortgaged property, rather than the difference between the loan balance and the price received at a foreclosure sale. For example, a 1933 Idaho statute specified that "no deficiency judgment may be entered in any amount greater than the difference between the mortgage indebtedness, plus the cost of foreclosure and sale and the reasonable value of the property" (Central Housing Committee, 1936, p. A-7). Other states permitted courts to invalidate foreclosure sales for less than fair value. Most states left the determination of fair value to the discretion of a local appraisal board or court rather than attempt to define "fair value" in statutes.

Several states imposed new limits on the length of time that a lender could seek a deficiency judgment after a foreclosure sale. For example, Iowa and Ohio enacted legislation limiting deficiency judgments to two years after a foreclosure sale (Skilton, 1944, p. 130). Other 
states abolished the right of lenders to seek deficiency judgments altogether. For example, a 1935 Montana statute specified that "Deficiency judgments are abolished in all actions for foreclosure of mortgages for balance of purchase price of real property" (Central Housing Committee, 1936, p. A-16). ${ }^{14}$

\section{WHICH STATES ADOPTED MORATORIA AND WHY?}

The 27 states that adopted foreclosure moratoria during 1933 and 1934 are listed in Table 1, and the geographic distribution of states with moratoria is shown in Figure 4. Moratoria were especially common among states in the Midwest and Great Plains, but they also were imposed by several states in the Northeast and Far West. Foreclosure moratoria were less common in New England, the Southeast, and Mountain West. ${ }^{15}$

Foreclosure moratoria generally applied to both farm and nonfarm residential mortgages. However, the pressure for foreclosure moratoria was particularly intense in midwestern states where farm foreclosure rates were especially high (Figure 5). Moratoria were less common in states with relatively low farm foreclosure rates, though a few, including New Hampshire, Pennsylvania, and Vermont, also imposed moratoria.

Alston (1984) investigates why some, but not all, states imposed foreclosure moratoria during the Depression. He estimates a logit regression model that includes a state's farm foreclosure rate, percentage of farms mortgaged, and percentage of farm mortgages held by federal land banks as explanatory variables. Alston argues that a state was more likely to impose a moratorium the

\footnotetext{
${ }^{14}$ See Central Housing Committee (1936), Poteat (1938), or Skilton (1944) for additional information about the provisions of moratoria and other legislation affecting the rights of mortgagors and lenders enacted in different states during the Depression.

${ }^{15}$ The source for Table 1 and Figure 4 is Skilton (1944, p. 78), which lists 27 states as having had a moratorium. Other sources omit Oregon, where a moratorium was authorized by a joint resolution of the state legislature, rather than by statute (Poteat, 1938), or omit both Oregon and Arkansas (Alston, 1984).

${ }^{16}$ The Federal Farm Loan Act of 1916 established 12 regional federal land banks to increase the supply of farm mortgage loans. See www.fca.gov/about/history/historyFCA_FCS.html.
}

\section{Table 1}

\section{State Mortgage Moratoria during the Great Depression}

\begin{tabular}{ll}
$\begin{array}{c}\text { States imposing } \\
\text { moratoria }\end{array}$ & $\begin{array}{c}\text { States not imposing } \\
\text { moratoria }\end{array}$ \\
\hline Arizona & Alabama \\
Arkansas & Colorado \\
California & Connecticut \\
Delaware & Florida \\
Idaho & Georgia \\
Illinois & Indiana \\
lowa & Kentucky \\
Kansas & Maine \\
Louisiana & Maryland \\
Michigan & Massachusetts \\
Minnesota & Missouri \\
Mississippi & New Jersey \\
Montana & New Mexico \\
Nebraska & Nevada \\
New Hampshire & Rhode Island \\
New York & Tennessee \\
North Carolina & Utah \\
North Dakota & Virginia \\
Ohio & Washington \\
Oklahoma & West Virginia \\
Oregon & Wyoming \\
Pennsylvania & \\
South Carolina & \\
South Dakota & \\
Texas & \\
Vermont & \\
Wisconsin & \\
& \\
\hline
\end{tabular}

SOURCE: Skilton (1944, p. 78).

higher its farm foreclosure rate, the higher its percentage of mortgaged farms, and the lower the percentage of mortgages held by federal land banks (which were less likely to foreclose than other lenders). ${ }^{16} \mathrm{He}$ finds that the farm foreclosure rate had the strongest impact on a state's decision to impose a moratorium.

As noted previously, moratoria were adopted in a few states with relatively low farm foreclosure 


\section{Figure 4}

\section{States Imposing Foreclosure Moratoria During the Great Depression}

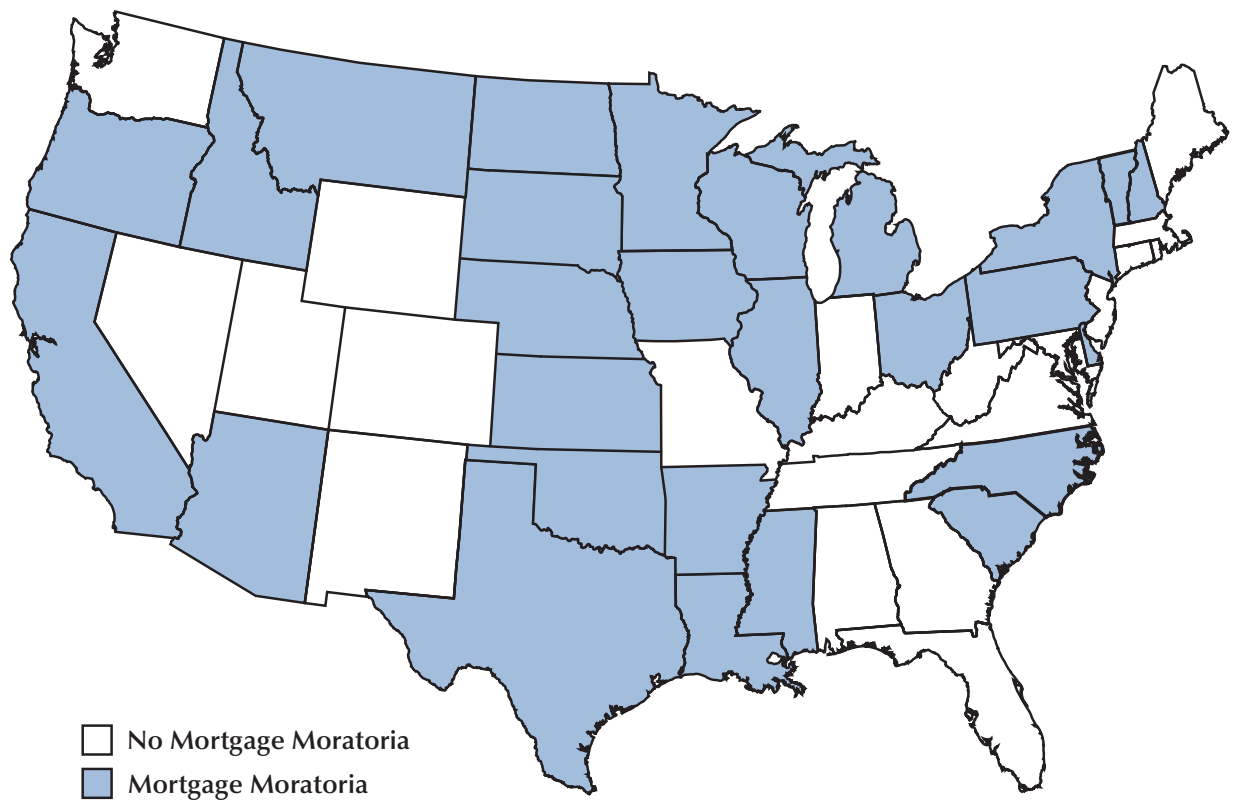

\section{Figure 5}

Average Farm Foreclosure Rates, 1929-1932

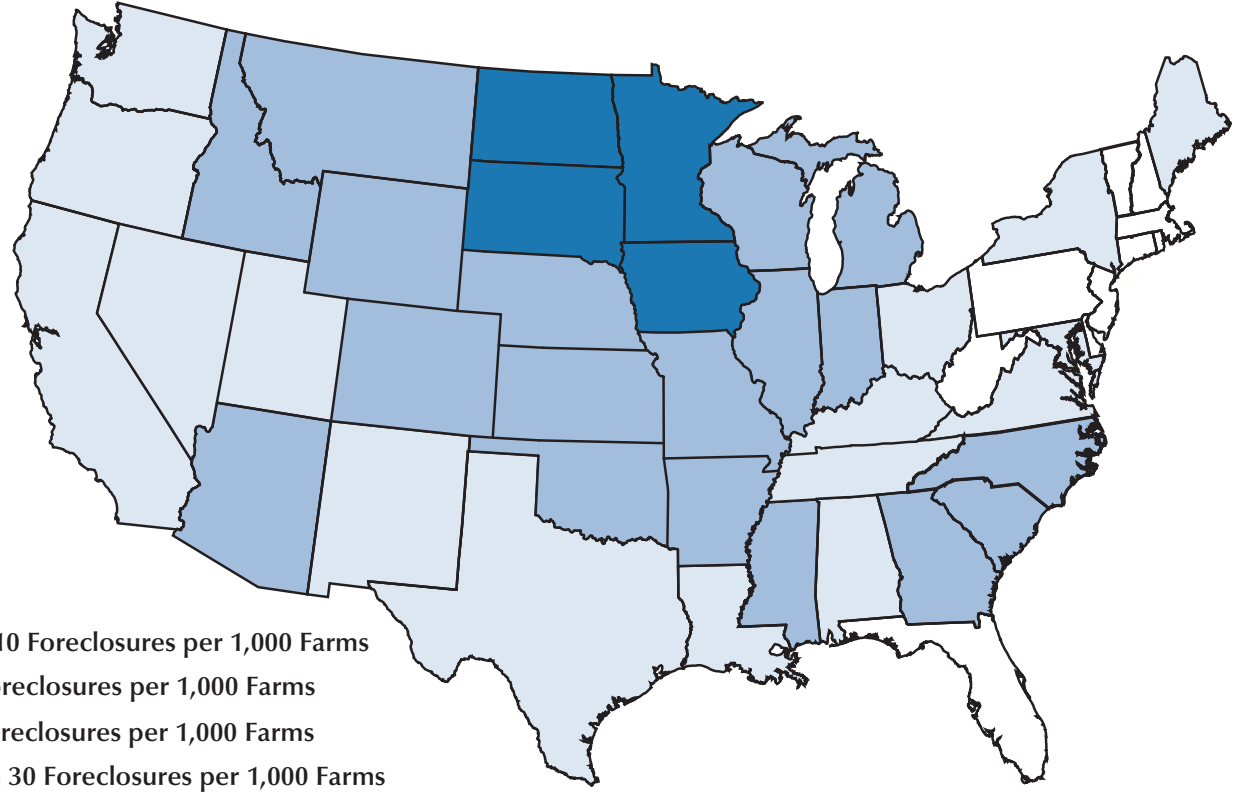




\section{Table 2}

\section{Regression Results}

\begin{tabular}{|c|c|c|c|c|}
\hline \multirow[b]{2}{*}{ Variable } & \multicolumn{4}{|c|}{ Model } \\
\hline & 1 & 2 & 3 & 4 \\
\hline Intercept & $\begin{array}{c}-1.7768 \\
(1.7752)\end{array}$ & $\begin{array}{c}-4.0343 \\
(3.4049)\end{array}$ & $\begin{array}{c}-1.5403 \\
(2.9175)\end{array}$ & $\begin{array}{c}-2.4317 \\
(3.6759)\end{array}$ \\
\hline Farm foreclosure rate & $\begin{array}{l}\mathbf{0 . 0 8 0 3}^{* *} \\
(0.0366)\end{array}$ & $\begin{array}{c}\mathbf{0 . 1 3 3 8}^{*} \\
(0.0695)\end{array}$ & $\begin{array}{c}-0.0183 \\
(0.0647)\end{array}$ & $\begin{array}{c}0.0419 \\
(0.1081)\end{array}$ \\
\hline Mortgaged farm percent & $\begin{array}{c}2.0338 \\
(3.4587)\end{array}$ & $\begin{array}{c}3.2953 \\
(4.3798)\end{array}$ & $\begin{array}{c}1.7109 \\
(3.7252)\end{array}$ & $\begin{array}{c}2.033 \\
(4.5092)\end{array}$ \\
\hline Federally held farm debt & $\begin{array}{c}-3.0984 \\
(2.5978)\end{array}$ & $\begin{array}{c}-3.4411 \\
(-3.1007)\end{array}$ & $\begin{array}{c}-\mathbf{6 . 4 9 6 5} * \\
(3.7163)\end{array}$ & $\begin{array}{c}-5.5301 \\
(3.8831)\end{array}$ \\
\hline Owner-occupied nonfarm homes & & $\begin{array}{c}3.5653 \\
(5.9059)\end{array}$ & $\begin{array}{c}2.9328 \\
(5.5364)\end{array}$ & $\begin{array}{c}3.6291 \\
(5.9293)\end{array}$ \\
\hline Foreclosure rate $\times$ farm population & & & $\begin{array}{c}\text { 0.0023* } \\
(0.0013)\end{array}$ & $\begin{array}{c}0.0017 \\
(0.0016)\end{array}$ \\
\hline Midwest & & $\begin{array}{c}-1.7877 \\
(1.8866)\end{array}$ & & $\begin{array}{c}-1.0099 \\
(2.0200)\end{array}$ \\
\hline South & & $\begin{array}{c}-0.5345 \\
(1.4734)\end{array}$ & & $\begin{array}{c}-0.6759 \\
(1.4776)\end{array}$ \\
\hline West & & $\begin{array}{c}-2.0764 \\
(1.4546)\end{array}$ & & $\begin{array}{c}-1.3836 \\
(1.5882)\end{array}$ \\
\hline Log likelihood & -27.3815 & -25.8424 & -25.6897 & -25.2482 \\
\hline Probability > chi-square & 0.0116 & 0.0493 & 0.0132 & 0.0537 \\
\hline
\end{tabular}

NOTE: Standard errors are indicated in parentheses; statistically significant coefficients are in bold. *Indicates significance at the 90 percent confidence level; ${ }^{* *}$ indicates significance at the 95 percent confidence level.

See the Appendix for data definitions and sources.

rates, and some states with high farm foreclosure rates did not impose moratoria. According to Skilton (1944), some states imposed moratoria in response to high numbers of nonfarm home mortgage foreclosures. Unfortunately, state-level data on nonfarm real estate foreclosures are not available for the early 1930s to test directly the impact of nonfarm foreclosures on moratoria adoption. Nevertheless, regional differences in farm foreclosure rates and the adoption of moratoria suggest that nonfarm foreclosures or other considerations may have influenced the decision to impose moratoria in some states.

Some evidence on why states imposed foreclosure moratoria is reported in Table 2, which presents a replication of Alston's (1984) logit model and some alternative specifications. The dependent variable in this set of cross-sectional regressions is a dummy variable, set equal to 1 for states that adopted a moratorium during 1933-34 and to 0 otherwise. The Appendix provides complete definitions and data sources for the variables included in the regressions.

Model 1 replicates Alston's model and shows his main result: the higher a state's farm foreclosure rate, the greater the likelihood the state would adopt a foreclosure moratorium. ${ }^{17}$ Model 2 includes the percentage of owner-occupied nonfarm homes as an additional explanatory variable.

\footnotetext{
${ }^{17}$ The coefficient estimates in Model 1 differ slightly from those reported in Alston (1984). Unlike Alston, I treated Arkansas and Oregon as having had moratoria, based on Skilton (1944), and used the farm foreclosure rate for 1932, rather than the average farm foreclosure rate for 1932 and 1933, as an explanatory variable.
} 


\section{Figure 6}

\section{Model 1: Pearson Residuals}

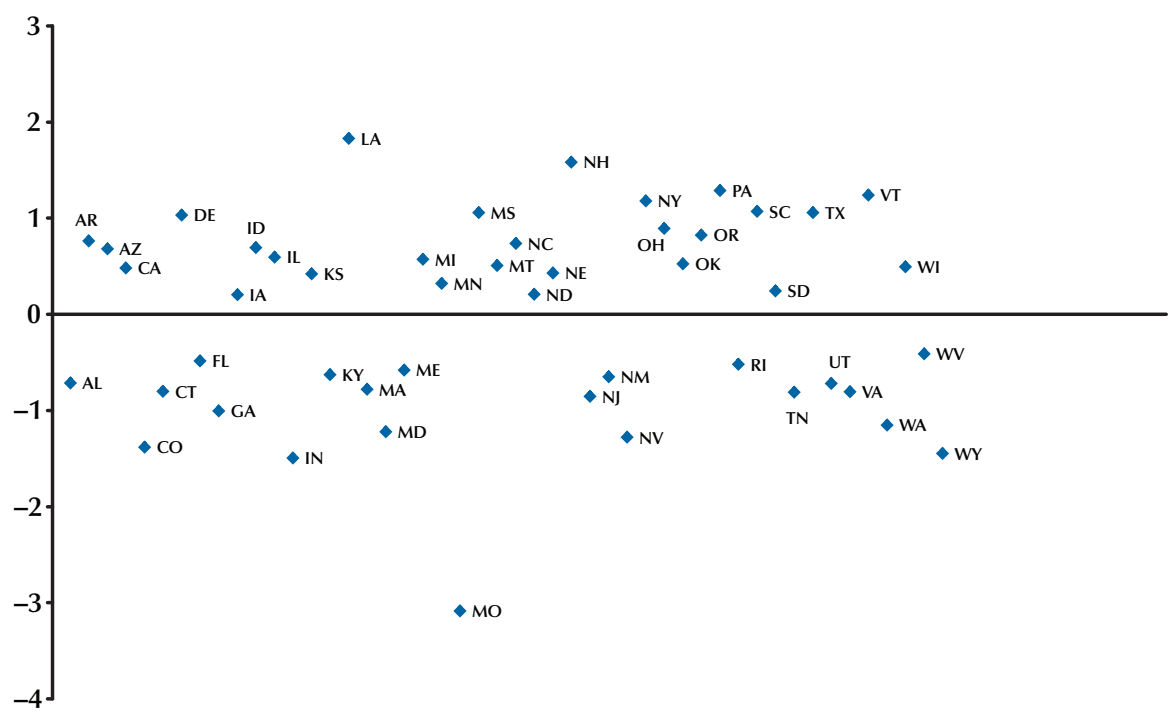

Presumably, the demand for moratoria legislation was greater where a high percentage of homes were mortgaged and, hence, at risk of foreclosure. Unfortunately, state-level data on the percentage of homes carrying a mortgage are not available for the 1930s. However, if owner-occupied homes were no less likely to be mortgaged than rented homes, a higher percentage of owner-occupied homes might reflect a greater demand for a foreclosure moratorium. Accordingly, I expect a positive coefficient on this variable. Consistent with expectations, the coefficient estimate in Model 2 for the percentage of owner-occupied homes is positive, though not statistically significant.

Model 2 also includes regional dummy variables. The coefficient estimates for the regional dummies indicate that relative to the Northeast (the omitted region), states in other regions of the country were less likely to adopt foreclosure moratoria. Stated differently, for a given rate of farm foreclosures, states in the Northeast were more likely to adopt foreclosure moratoria than states elsewhere. This suggests that nonfarm mortgage distress had a greater influence on the decision to adopt moratoria among the more urbanized northeastern states than it did in other regions of the country. However, the coefficients on the regional dummy variables are not statistically significant. ${ }^{18}$

Model 3 further refines the analysis by testing whether the influence of farm foreclosures on moratoria adoption was stronger in states with relatively high farm populations. To test this conjecture, Model 3 includes the interaction of the farm foreclosure rate and the percentage of state population located on farms. The coefficient estimate on the interaction term (foreclosure rate $\times$ farm population) is positive and statistically significant, and the coefficient on the farm foreclosure rate is near zero, which supports this hypothesis. The impact of a given farm foreclosure rate was greater in states with relatively larger farm populations.

Finally, Model 4 adds regional dummy variables to the previous specification. The coefficients on the regional dummies are again negative, suggesting a relatively low demand for moratoria

\footnotetext{
18 The test statistic for a likelihood ratio test of the hypothesis that the coefficients on the regional dummies are jointly zero is 3.08 ( $p$-value $=0.38)$.
} 
among states outside the Northeast. However, the contribution of the regional dummies to the model's explanatory power is not statistically significant. ${ }^{19}$

For additional insights about why states adopted (or did not adopt) foreclosure moratoria, I examined the residuals from the logit models reported in Table 2. The Pearson residuals for Model 1 are shown in Figure $6 .^{20}$ The residuals for states that adopted moratoria are greater than or equal to zero, whereas those for states that did not adopt moratoria are less than or equal to zero. The closer a state's residual is to zero, the more accurately the model explains the state's decision to impose (or not impose) a moratorium. Thus, the large positive residual for Louisiana indicates that the model explains relatively little of the state's decision to impose a moratorium. Similarly, the model explains relatively little of Missouri's decision not to adopt a moratorium. Missouri had a comparatively high farm foreclosure rate and, given that fact, Model 1 predicts that Missouri would have imposed a moratorium.

Additional information helps explain the anomalous behavior of some states. For example, Louisiana was the last state to adopt a debt moratorium (in July 1934). Soon thereafter, the legislation authorizing the moratorium was amended to grant broad authority to a state debt commissioner to "suspend all laws relating to the collection of fundamentally all types of debts in existence at the time of the passage of the act" (Skilton, 1944, pp. 83-84). In effect, the state imposed a general moratorium on all debts, not just real estate mortgage debt. The breadth of the moratorium thus might help explain why Louisiana imposed a moratorium, despite only a modest level of farm distress.

New York also enacted an unusually broad foreclosure moratorium that extended to commercial real estate, as well as to farm and nonfarm

\footnotetext{
${ }^{19}$ The test statistic for a likelihood ratio test of the hypothesis that the coefficients on the regional dummies are jointly zero is 0.88 ( $p$-value $=0.83)$.

${ }^{20}$ The logit models were estimated using Stata/MP 10.0. The basic Pearson residual is the difference between the actual and modelpredicted values of the dependent variable, divided by the estimated standard deviation of the predicted values. See Stata/MP 10.0 for more details about the calculation of the Pearson residual.
}

residential property. According to Skilton (1944, pp. 76-77), property management companies and other real estate interests had considerable influence on the moratorium legislation, and "The lobbying of real estate operators was sufficient... to defeat Governor Lehman's original idea that a moratorium should be limited to farms and homes." Thus, like Louisiana, the breadth of the moratorium may help explain why Model 1, which captures only the effects of farm distress, does not explain well the imposition of a foreclosure moratorium in New York.

Differences in the prevailing state laws governing mortgage foreclosure might also help account for the model's failure to explain well the moratoria decisions of some states. For example, neither Indiana nor Missouri adopted a foreclosure moratorium during the Depression, despite relatively high levels of farm distress. However, a federal study concluded that the demand for moratoria was low in both states because their prevailing foreclosure laws were already comparatively favorable to borrowers (Central Housing Committee, 1936).

\section{ECONOMIC IMPACT OF FORECLOSURE MORATORIA}

Governments cause both immediate and long-term effects when they rewrite the terms of contracts between private parties. The immediate impact is redistribution of wealth between the parties of the affected contracts. The temporary foreclosure moratoria and most other changes in state mortgage laws enacted during the 1930s favored borrowers over lenders. These actions interfered with the rights of lenders to seize collateral pledged by borrowers to guarantee payment of their mortgages. Several states also enhanced the rights of borrowers to redeem foreclosed property and limited the rights of lenders to sue for deficiency judgments.

One immediate effect of mortgage relief legislation during the Depression was reduced farm foreclosure rates (Rucker and Alston, 1987). ${ }^{21}$

\footnotetext{
${ }^{21}$ I am unaware of any research on the effects of relief legislation on nonfarm home mortgage foreclosure rates.
} 
However, over the longer run, foreclosure moratoria and other changes in mortgage laws may have made loans costlier or more difficult to obtain. Critics argued that foreclosure moratoria induce lenders to restrict the supply of loans and raise interest rates to compensate for the possibility that their right to foreclose on delinquent loans or to collect deficiency judgments will be constrained. According to a 1936 federal government report,

Statutes which provide a lengthy, expensive, complicated or otherwise burdensome foreclosure procedure, or which interpose a long period of redemption before title and possession to the mortgaged property can be obtained, have a tendency to increase interest rates and security requirements throughout the jurisdiction, since prospective lenders naturally take into account the procedure available for realizing the debt out of the security when determining the conditions on which they will be willing to make loans. (Central Housing Committee, 1936, p. 3)

The same report noted that in 1933-34 many states elected to disregard such objections because it was widely believed that "unrestricted foreclosure of farm and home mortgages under the circumstances prevailing at the time would have deprived large numbers of persons of essential shelter and protection, and would have left them without the necessary means for earning a living. Such wholesale evictions might have seriously endangered basic interests of society" (Central Housing Committee, 1936, p. 2). Hence, in many states, the societal costs of widespread foreclosures were viewed as exceeding the costs of reduced loan supply and higher interest rates borne by prospective borrowers. Furthermore, foreclosure moratoria generally were viewed as expedients to buy time for the economy to recover and for the federal government to initiate programs to refinance delinquent mortgages (Skilton, 1944, pp. 73-77). Even lenders may have benefited from foreclosure moratoria in the short run. Although individual lenders had an incentive to foreclose to recoup losses on delinquent mortgages, a high number of foreclosures in an area could reduce property values and thereby cause still more foreclosures. Thus, foreclosure moratoria might halt a downward spiral in property values and benefit lenders as a whole. ${ }^{22}$

Although the economic and societal benefits of lower foreclosure rates are difficult to measure, research shows that the foreclosure moratoria of the Great Depression did impose costs on future borrowers. Alston (1984) investigates the impact of foreclosure moratoria in an empirical model of the farm mortgage market. He argues that foreclosure moratoria encouraged lenders to reduce the supply of loans, resulting in fewer loans made and, possibly, higher average interest rates. Consistent with this hypothesis, Alston (1984) finds that private lenders made significantly fewer loans in states that imposed moratoria and tended to charge higher interest rates on the loans they did make.

Rucker (1990) extends Alston's (1984) study to investigate differences in the impact of mortgage relief legislation on the supply of loans offered by different types of private lenders. In the 1930s, most farm mortgages were issued by local commercial banks, private individuals, insurance companies, and federal land banks. Insurance companies tended to be larger and more diversified and to have a lower cost of funds than did banks and individual lenders. Their size and cost advantages enabled insurance companies to attract lower-risk borrowers and, consequently, experience lower delinquency rates. Insurance companies generally were also more willing to grant extensions to delinquent borrowers. Hence, the costs imposed by mortgage relief legislation should have been lower for insurance companies than for other private lenders. Rucker (1990) finds that, indeed, mortgage relief legislation led to significantly larger reductions in the supply of loans from commercial banks and individual lenders than from insurance companies. ${ }^{23}$ Both

\footnotetext{
${ }^{22}$ Kahn and Yavas (1994) examine the short- and long-run effects of changes in foreclosure laws (especially how they affect borrower and lender behavior and borrower welfare) in a simple theoretical model of the mortgage market in which renegotiation of loan contracts is possible. Jaffe and Sharp (1996) describe the economics of foreclosure moratoria in the context of alternative legal theories of contracts.

${ }^{23}$ In his econometric analysis, Rucker (1990) treated legislation that limited deficiency judgments or enhanced redemption rights for
} 
Alston (1984) and Rucker (1990) conclude that mortgage relief legislation caused significant reductions in the aggregate supply of loans in states that enacted such legislation.

The findings of Alston (1984) and Rucker (1990) on the effects of mortgage relief legislation during the 1930s are consistent with other studies that find significant effects of state mortgage laws on local lending markets. Meador (1982), for example, finds that loan interest rates tend to be higher in states with lengthy or costly foreclosure processes or those that prohibit deficiency judgments. More recently, Pence (2006) finds that mortgage loans are, on average, some 3 to 7 percent smaller in states in which foreclosure requires a court action than in states with nonjudicial foreclosure processes, again consistent with the hypothesis that the supply of loans is lower in states in which foreclosure is more costly. ${ }^{24}$

\section{CONCLUSION}

In 2008, residential real estate foreclosure rates are at their highest levels since the Great Depression. Not surprisingly, policymakers are considering actions similar to those taken during the Depression to limit foreclosures. The federal government responded to mortgage distress during the Depression by creating new federal agencies to refinance delinquent mortgages, insure and finance newly issued mortgages, and expand federal farm credit programs. By contrast, many state governments imposed moratoria on foreclosures, limited deficiency judgments, and enhanced the rights of borrowers to redeem foreclosed property. By halting foreclosures temporarily, states hoped to buy time for economic recovery to take hold, for household incomes and property values to rise, and for the federal government to refinance delinquent mortgages.

The earliest calls for mortgage relief were in farming regions, and states with high farm fore-

borrowers, as well as foreclosure moratoria, as forms of relief legislation, whereas Alston (1984) focused exclusively on moratoria.

${ }^{24}$ Pence (2006) compares bordering census tracts located in different states and controls for a variety of borrower, policy, and other census tract characteristics. closure rates were more likely to impose moratoria (Alston, 1984). Additional evidence indicates that farm foreclosures had a greater impact on the decision to impose moratoria in states in which the farm population comprised a relatively high percentage of total state population.

Moratoria were imposed in a few states with comparatively little farm mortgage distress, suggesting that urban mortgage distress or other factors influenced the decision to impose moratoria in some states. For example, in New York, lobbying by commercial real estate interests helped shape legislation for a broad moratorium covering farm, urban residential, and commercial real estate mortgage foreclosures.

In most states, foreclosure moratoria were limited to borrowers who had some chance of paying or refinancing their loans. Relief often was denied to borrowers judged to have little prospect of ever paying off their mortgage.

Foreclosure moratoria resulted in both winners and losers. Although the rights of lenders to foreclose on collateral or to seek deficiency judgments were restricted, relief legislation did apparently contribute to a reduction in farm failures (Rucker and Alston, 1987).

At least some contemporaries recognize that even temporary foreclosure moratoria can impose costs on future borrowers. Alston (1984) and Rucker (1990) find that lenders reduced the supply of loans in response to diminution of their rights to foreclose on collateral or to seek deficiency judgments. Thus, while to many observers the economic and societal costs of widespread real estate foreclosures were overwhelming, foreclosure moratoria and other relief legislation transferred at least some of those costs to future borrowers. The evidence from the use of foreclosure moratoria during the Great Depression demonstrates how legislative actions to reduce foreclosures can impose costs that should be weighed against potential benefits.

\section{REFERENCES}

Alston, Lee J. "Farm Foreclosures in the United States During the Interwar Period." Journal of Economic History, December 1983, 43(4), pp. 885-903. 
Alston, Lee J. “Farm Foreclosure Moratorium Legislation: A Lesson from the Past.” American Economic Review, June 1984, 74(3), pp. 445-57.

Bernanke, Ben S. "Nonmonetary Effects of the Financial Crisis in the Propagation of the Great Depression." American Economic Review, June 1983, 73(3), pp. 257-76.

Bridewell, David A. The Federal Home Loan Bank Board and its Agencies: A History of the Facts Surrounding the Passage of the Creating Legislation, The Establishment and Organization of the Federal Home Loan Bank Board and the Bank System, The Savings and Loan System, The Home Owners' Loan Corporation, and the Federal Savings and Loan Insurance Corporation. Washington, DC: Federal Home Loan Bank Board, 1938.

Bridewell, David A. and Russell, Horace. "Mortgage Law and Mortgage Lending." Journal of Land and Public Utility Economics, August 1938, 14(3), pp. 301-21.

Central Housing Committee. "Special Report No. 1 on Social and Economic Effects of Existing Foreclosure Procedure and Emergency Moratorium Legislation.” Horace Russell, Chairman. Submitted April 2, 1936.

Federal Home Loan Bank Board. Fifth Annual Report. June 30, 1937.

Jaffe, Austin J. and Sharp, Jeffery M. "Contract Theory and Mortgage Foreclosure Moratoria.” Journal of Real Estate Finance and Economics, January 1996, 12(1), pp. 77-96.

Kahn, Charles M. and Yavas, Abdullah. "The Economic Role of Foreclosures." Journal of Real Estate Finance and Economics, January 1994, 8(1), pp. 35-51.

McDonald, Daniel and Thornton, Daniel L. "A Primer on the Mortgage Market and Mortgage Finance.” Federal Reserve Bank of St. Louis Review, January/February 2008, 90(1), pp. 31-46; research.stlouisfed.org/publications/review/08/01/ McDonald.pdf.
Meador, Mark. "The Effects of Mortgage Laws on the Home Mortgage Rates." Journal of Economics and Business, 1982, 34(2), pp. 143-48.

Morton, Joseph E. Urban Mortgage Lending: Comparative Markets and Experience. Princeton, NJ: Princeton University Press, 1956.

Pence, Karen M. "Foreclosing on Opportunity: State Laws and Mortgage Credit.” Review of Economics and Statistics, 2006, 88(1), pp. 177-82.

Poteat, J. Douglass. "State Legislative Relief for the Mortgage Debtor During the Depression." Law and Contemporary Problems, 1938, 5, pp. 517-44.

Rucker, Randal R. “The Effects of State Farm Relief Legislation on Private Lenders and Borrowers: The Experience of the 1930s." American Journal of Agricultural Economics, February 1990, 72(1), pp. 24-34.

Rucker, Randal R. and Alston, Lee J. "Farm Failures and Government Intervention: A Case Study of the 1930s." American Economic Review, September 1987, 77(4), pp. 724-30.

Skilton, Robert H. Government and the Mortgage Debtor (1929 to 1939). PhD Dissertation, University of Pennsylvania, Philadelphia, 1944.

Sloan, Steven. "Minnesota Foreclosure Measure Draws Veto.” American Banker, June 3, 2008; www.americanbanker.com/article.html?id=200806 02TJH8JBQ8\&queryid=982795036\&hitnum=.

Wheelock, David C. "The Federal Response to Home Mortgage Distress: Lessons from the Great Depression.” Federal Reserve Bank of St. Louis Review, May/June 2008, 90(3), pp. 133-48; research.stlouisfed.org/publications/review/08/05/ Wheelock.pdf. 


\section{APPENDIX}

\section{Variable Definitions and Data Source Information}

\begin{tabular}{|c|c|c|}
\hline Variable name & Definition & Source \\
\hline Moratorium & $\begin{array}{l}\text { Dummy variable equal to } 1 \\
\text { for states with mortgage } \\
\text { moratorium in 1933-34 }\end{array}$ & $\begin{array}{l}\text { Skilton, Robert H. Government and the } \\
\text { Mortgage Debtor (1929 to 1939). } \\
\text { PhD Dissertation, University of Pennsylvania, } \\
\text { Philadelphia, 1944, p. } 78 .\end{array}$ \\
\hline Farm foreclosure rate & $\begin{array}{l}\text { Farm foreclosures per 1,000 } \\
\text { mortgages in } 1932\end{array}$ & $\begin{array}{l}\text { U.S. Department of Agriculture. } \\
\text { "The Farm Real Estate Situation, 1930-31." } \\
\text { Bureau of Agricultural Economics, } \\
\text { circular no. 209, } 1931 .\end{array}$ \\
\hline Mortgaged farms (percent) & $\begin{array}{l}\text { Percentage of farms mortgaged } \\
\text { in 1930, calculated as } \\
\text { (mortgaged farms/all owned } \\
\text { farms) }\end{array}$ & $\begin{array}{l}\text { U.S. Department of Commerce. } \\
\text { Statistical Abstract of the United States: } 1932 . \\
\text { Washington, DC: U.S. Government Printing } \\
\text { Office, 1932, Table 548, p. } 589 .\end{array}$ \\
\hline Federally held farm debt & $\begin{array}{l}\text { Percent of mortgage debt held } \\
\text { by federal land banks, } \\
\text { calculated as (sum of amount } \\
\text { of loans closed } 1917 \text { to 1932/ } \\
\text { total farm mortgage debt } \\
\text { in 1932) }\end{array}$ & $\begin{array}{l}\text { U.S. Department of Agriculture. } \\
\text { Miscellaneous Publication No. 478, } \\
\text { "Farm Mortgage Credit Facilities in the United } \\
\text { States." Washington, DC: U.S. Government } \\
\text { Printing Office, 1942, Table 64, p. } 221 \text { and } \\
\text { Table 78, p. } 245 .\end{array}$ \\
\hline $\begin{array}{l}\text { Owner-occupied nonfarm } \\
\text { homes (percent) }\end{array}$ & $\begin{array}{l}\text { Percentage of owned nonfarm } \\
\text { homes in 1930, calculated as } \\
\text { (sum of owned nonfarm } \\
\text { homes/total nonfarm homes) }\end{array}$ & $\begin{array}{l}\text { U.S. Department of Commerce. } \\
\text { Fifteenth Census of the United States: } 1930 . \\
\text { Population, Volume VI, Table 42, p. } 35 . \\
\text { Washington, DC: U.S. Government Printing } \\
\text { Office, 1931. }\end{array}$ \\
\hline Farm population & $\begin{array}{l}\text { Percentage of population on } \\
\text { farms in } 1930\end{array}$ & $\begin{array}{l}\text { U.S. Department of Commerce. } \\
\text { Statistical Abstract of the United States: } 1932 . \\
\text { Washington, DC: U.S. Government Printing } \\
\text { Office, 1932, Table 36, p. } 47 .\end{array}$ \\
\hline
\end{tabular}


